\author{
Daria E. Jaremen \\ Andrzej Rapacz \\ Wrocław University of Economics \\ Faculty of Economics, Management and Tourism in Jelenia Góra \\ Department of Marketing and Management of Tourism \\ daria.jaremen@ue.wroc.pl \\ andrzej.rapacz@ue.wroc.pl
}

\title{
CULTURAL EVENTS AS A METHOD FOR CREATING A NEW FUTURE FOR MUSEUMS
}

\begin{abstract}
In the situation of insufficient subsidies for the substantive activities of museums, primarily the ones funded by the local governments, as well as low attendance of visitors, not really interested in the traditional offer of such institutions, there is an urgent need to extend it with additional elements corresponding to the expectations of a contemporary client. The observation of the thriving museums in Poland and worldwide indicates that cultural events represent such an attractive component which expands the museum offer. The article presents an attempt of explaining the role of cultural events in developing a museum product based on the analysis of a specific case of the Municipal Museum Gerhart Hauptmann's House in Jelenia Góra-Jagniątków.
\end{abstract}

Keywords: museum, museum product, cultural events.

Museums without visitors would be like life less empty halls with no purpose Ch. Waltl

\section{INTRODUCTION}

The crisis in traditionally approached humanistic education, low attendance, transformations in social life, demographic changes, digitization of culture and participation in it, limited political autonomy of cultural institutions and uncertainty over the future, define the conditions in which museums are supposed to function in Poland. In many cases, especially regarding museums operating as self-governing units, a struggle for survival is always present, with the crucial tool to tackle this taking the form of activities aimed at increasing visitor attendance. The growing number of visitors, on the one hand, justifies the need for museums and, on the other, supports their budgets with additional income. Cultural events organized by museums however represent one of the important undertakings available to raise visitor turnout. It can be argued that currently such events are an integral and indeed a prevailing part of the service offered by most museums, and simultaneously a vital instrument for creating a new future for them.
The purpose of the article is to present the significance of cultural events for developing the product offered by contemporary museums, based on the example of the Gerhart Hauptmann Museum (GHM) in Jelenia Góra-Jagniątków. The article highlights the reasons determining the importance of cultural activities and the place of cultural events included in the offer of contemporary museums. It describes the current situation of museums in Poland, with particular emphasis on the funding sources of their activities, changes in attendance rates and the requirements of museum visitors. For this purpose secondary information sources were reviewed, along with an analysis of publications covering these issues. The discussion was illustrated using the GHM case study. In the first half of 2016, questionnaire interviews with 25 museum visitors and in-depth interviews with the director and members of the Museum Board were carried out for the purposes of the case study. 


\section{A CULTURAL EVENT AS AN ELEMENT OF A MUSEUM'S OFFER}

The term 'cultural event' consists of two concepts which should be defined. The first is the 'cultural' category ${ }^{1}$ which here means 'referring to culture' rather than - as commonly used in Polish - 'impeccable manners of a well-behaved person'. However, the essence of the term 'cultural event' is not only ingrained in the 'relationship with culture' as the overall offer of a museum as a cultural institution is of a culture-oriented nature. The centre of gravity of this term lies in the word 'event'. The Dictionary of Polish published by the Polish Academy of Sciences (PWN) (https://sjp.pwn.pl/sjplocal/slowniki) defines this term as referring to 'an important event or an outstanding achievement in some field'. An event does not stand for a typical, ordinary happening, but rather something special, episodic, limited in time. In order to highlight its uniqueness, the word 'special' is added in English. The most frequently cited researchers, in terms of events and event tourism, emphasize that events represent "special, unique moments celebrated in a sublime atmosphere and involving a respective ritual to meet specific needs" (GOLDBLATT 2002, p. 6), and "occurring once or infrequently, outside a regular program and activity of the funding and organizing entity" (GETZ 2005, p. 7). They take the form of "gatherings of people, usually lasting from a few hours to several days, organized to celebrate, honour, sell, teach, or observe human efforts" (MATTHEWs 2008, 2). The subject literature highlights such features as celebration/solemnity (MATTHEWs 2016), social usefulness, purposefulness (GETZ 2016, pp. 593631), uniqueness (BLADEN et al. 2012, p. 3) and diversity in terms of size and effects (JAGO \& SHAW 1998) duration and objectives as well as spatial and temporal character (GETZ 2008, pp. 403-428). Therefore, a cultural event is a special, purposeful, designed, spatially and temporally defined endeavour referring to the creation and/or dissemination of culture. Due to the wide meaning of the term 'culture' (material and non-material products of mankind) practically anything can become the subject matter for such events. It could be art, literature, music, science or technology. Any event held 'under the roof' of a museum, i.e. a cultural institution, can be qualified as cultural, just as in the case of hospitality services, regardless of their nature (e.g. a transfer of visitors), they can be classified as such as long as they are provided by a hotel. The events discussed often make a visit to a museum an unforgettable experience, as they influence their participants emotionally. They engage visitors intellectually (live performances) and also involve them in active and creative participation (meet-ings with interesting people or taking part in literary workshops). As a result of physical participation in an event, the immersion in such an experience is much deeper due to the visitors' contributions and their key role in the entire happening. Such events also broaden the range of motivations for which a particular museum is visited and encourage re-visitation by creating higher value for a client, along with stimulating his/her appetite for new, even more interesting events. The communication and mediaoriented dimension of the events organized in a museum supports its marketing activities and develops its entrepreneurial image, which facilitates applying for funding from sponsors and donors. The events discussed represent, however, a product which requires a high level of professionalism from its organizer, both at the designing and execution stage, whereas its production is often compared to a movie or a live performance (ALLEN 2009, p. 1).

\section{THE SITUATION OF MUSEUMS IN POLAND}

Over the last 25 years the functioning of museums in Poland has been determined by the market economy, local government reform and amendments to the Act on Museums. These changes have primarily manifested themselves in the sphere of organization, supervision and funding (i.e. sources and level) of cultural units. Museums were divided, according to the criteria of their organizer (i.e. the establishing, running and funding entity) into six groups: state museums (21) supervised by the Ministry for Culture and National Heritage (MCNH) or the Ministry for National Defence; museums run in cooperation by $\mathrm{MCNH}$ and other institutions (20); local government museums (319), for which the organizing entity is a województwo, powiat or gmina; church museums (12); museums founded by individuals (212); museums established by businesses $(136)^{2}$. Therefore, museums in Poland are financed from either national or local government (regional or local) budgets, or by the private sector. The research initiated by the National Institute of Museology and Collection Protection (NIMCP), excluding private museums and those established by individuals, revealed the following facts in the financial management of both state and local government museums (MURZYN-KUPISZ 2016, pp. 93-95):

- the main part (two-thirds) of all museum revenues come from an earmarked public subsidy for current activities (63.6\% of total revenues) and a specific subsidy (3.8\%),

- museums also receive specific subsidies from bodies other than the organizers (e.g. European funds) which, on average, account for around one twentieth of all funds at their disposal,

- ca $15.7 \%$ revenues are generated by museums themselves in the form of admission fees, 
museum publications and services (e.g. guided tours); almost half of their own revenues come from ticket sales,

- other revenues amount to around $11.6 \%$.

The above data show that nearly $27 \%$ of total museum revenues come from sources other than the public subsidy. This poses a significant threat to the stability of museums functioning in Poland. An acceptable and secure share of funds not provided by the basic public subsidy should not exceed $17 \%$ of total museum revenues (FOLGA-JANUSZEWSKA 2008, p. 16). B. LORD \& G.D. LORD (1997) claim that national and local government subsidies remain the most important funding sources for museums worldwide and account for about $90-100 \%$ of total revenues for many national, regional and local museums, whereas the average level is $60-70 \%$. The budgets for museums, whose primary role is to protect their collections, is obtained from public subsidies usually amounting to $55-70 \%$. This share is increased by an additional $10-15 \%$ when a museum is highly involved in educational activities. Usually $55-70 \%$ of the budgets for museums, whose primary function is the protection of collections, is made up of public subsidies. This share is higher by an additional $10-15 \%$ when a museum becomes extensively involved in educational activity. It should be pointed out that limiting public subsidies always significantly disturbs the functioning of museums. The recent budget cuts in Great Britain can serve as the example. They caused the closure of, at least, every fifth to visitors. For the same reason, in 2015, $8 \%$ of British museums were forced to introduce admission fees (Museums Association 2015, p. 5) and in 2016 yet another 2\% started collecting such fees (Museums Association 2017, p. 12). It is worth adding at this point that the most frequently visited museums in the world, except for the Louvre, are free of charge for visitors (Themed Entertainment Association 2016, KRUCZEK 2017, p. 41).

Despite the fact that "discussion of the desirability for increasing museum revenues through higher attendance is no longer voiced, as it became clear that these institutions are non-profit not only in name but also by nature, thus to fulfilling their educational, artistic and scientific mission must be carried out with the support of funding sources other than just ticket sales growth" (FOLGA-JANUSZEWSKA 2008, p. 38). It is also clear that public subsidies for running them are far from sufficient, often covering just the essential personnel costs (salaries and benefits) and non-personnel expenses (energy, insurance, taxes and fees). In this situation, both attendance and revenues from admission ticket sales are not as insignificant as they may seem. Moreover, the number of visitors continues to be the basis for determining all museum statistics and one of the parameters in assessing their functioning. In these conditions it is worth making every effort to achieve higher attendance, which also corresponds to a museum's mission which is not limited to the protection of cultural heritage but remains much more extensive and includes its provision and popularization among visitors.

The market for museums in Poland is systematically expanding through new openings. The emerging museums are frequently very modern. Their infrastructure and approach, as well as their ways of exhibiting collections are not different from the highest world standards, and above all reflect the preferences of contemporary visitors (e.g. Warsaw Uprising Museum, Museum of the History of Polish Jews in Warsaw). The market entry of new museums additionally encourages competition, not only in terms of visitors, but also of donors and donations.

Attendance at Polish museums is relatively low. According to the report by the European Commission Special Eurobarometer 399, in 2013 only 24\% of Poles visited museums at least once, compared to $37 \%$ in the 27 European Union countries. The highest percentage visiting museums at least once a year was recorded in Sweden (76\%), Denmark (62\%), Holland (60\%), whereas the lowest were in Greece (16\%), Portugal (17\%), Cyprus (18\%) and Romania (21\%) (Special Eurobarometer... 2013, p. 12). In this ranking Poles are fifth from bottom. A drastic decline in attendance at Polish museums, taking into account both domestic and foreign visitors, was recorded at the beginning of the 90s (STASIAK 2005, pp. 117-134). Although this indicator has increased steadily in recent years (in 2015 - against 2005 - higher by 14.8 million visits i.e. by $80 \%$ - see Fig. 1), it should be observed that this increase is largely attributable to the attendance achieved by only $2 \%$ of museums, i.e. twenty so-called TOP museums out of 926 functioning in Poland in the year of the study (authors' calculations based on Museums in Poland... 2016, p. 107).

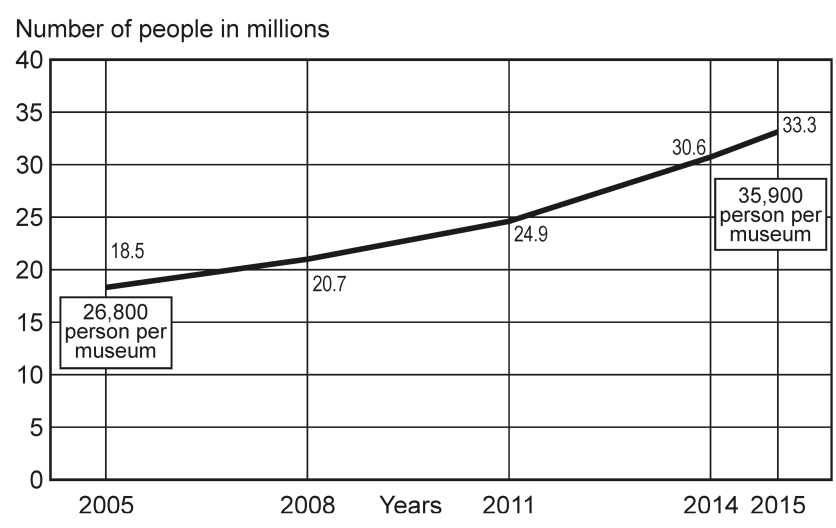

Fig. 1. Museum attendance in Poland: 2005-15 Source: authors' estimations based on Kultura $w 2007$

(2008, p. 60), Kultura w 2009 (2010, p. 205), Kultura w 2015 (2016, p. 107) 
Such museums as Łazienki Królewskie in Warsaw, Auschwitz-Birkenau Memorial and Museum, Wawel Royal Castle in Kraków and new ones - e.g. Oskar Schindler's Enamel Factory and Rynek Podziemny (Under the Market Square), branches of the Historical Museum of the City of Kraków established in 2010, as well as the Warsaw Uprising Museum (2004) and Museum of the History of Polish Jews in Warsaw (2005) - attracted a total of 14.9 million visits (45\% of all visits to Polish museums in 2015). It should also be highlighted that in the period 2005-15 the number of museums increased by $34.2 \%$. The number of visits per museum in 2015 amounted to $c a 36000$ and was also higher than in 2005 (by 34\%). However, this increase applies to some museums only and remains diversified spatially. High average attendance was recorded in 2015 in the following provinces: Małopolskie, Mazowieckie, Śląskie and Podkarpackie; and low in Podlaskie and Opolskie (Fig. 2). Lower than average attendance rates for all museums refer to the those in as many as ten regions, including Dolnośląskie - 22917 visits (Museums in Poland 2016, p. 40).

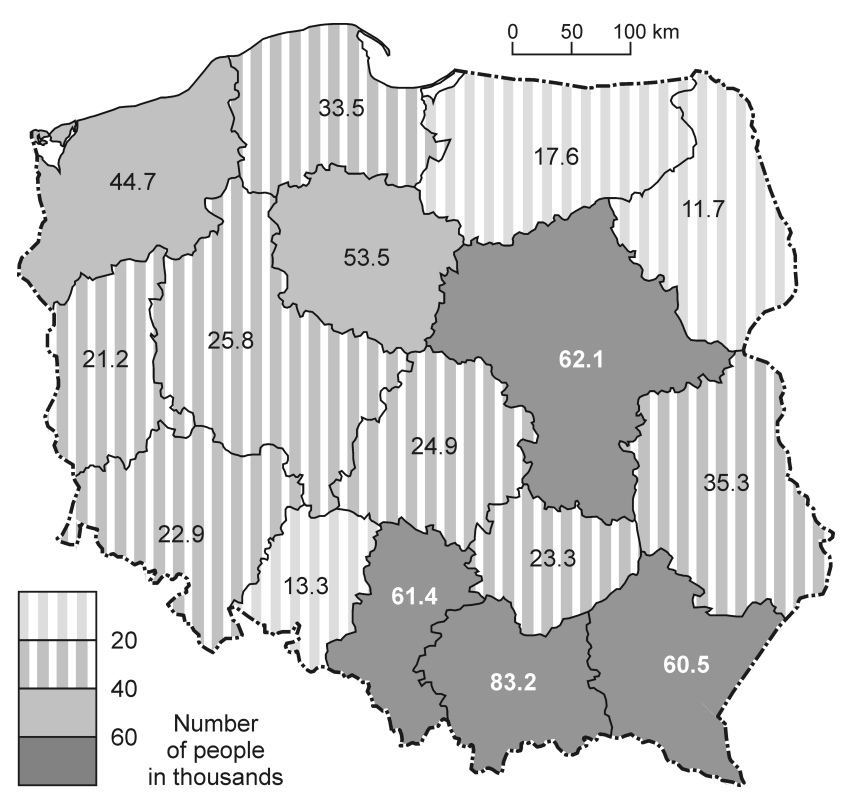

Fig. 2. Average attendance in museums in Poland by regions: 2015

Source: authors - based on Museums in Poland... (2016, p. 40)

The above, very briefly ${ }^{3}$ presented situation, generates major challenges for the managers of museums. It acts as an incentive to seek effective ways to increase revenues, primarily self-generated, and the specific subsidies offered under national and European cultural support programs. Attracting visitors willing to pay admission fees is important for supplementing museum budgets. It also remains one of many criteria for project evaluation in the process of grant application. How to attract visitors, however, remains a matter for museum managers' creativity, along with their marketing skills supported by an extensive knowledge of customer expectations.

\section{THE EXPECTATIONS OF CONTEMPORARY MUSEUM VISITORS}

In view of the proliferation of new information and communication technologies and media, the expectations and preferences of museum visitors are definitely changing. Recent discussions carried out among museologists indicate several significant transformations observed in visitors' behaviour. They expect that ${ }^{4}$ :

- in one place and in a short time a museum will offer various incentives and exciting impressions, stimulating many senses (multi-sensory experiences);

- they will become involved and immersed in the surrounding reality, as they desire to interact with it and feel the atmosphere of the specific time and events presented by the museum (immersion);

- they will be engaged, in an attractive way, in an interplay or a game, and the museum will provide them with entertainment and sometimes physically active ways of spending time, as well as challenge them intellectually;

- during their visit they will turn into researchers performing individual explorations and discoveries, experiencing, touching and trying just by themselves;

- they will not have certain behaviours imposed, i.e. walking along marked paths, in set groups and keep tour time discipline, instead they expect free choice and an opportunity to find their own way of getting to know the ideas which the museum wants to get across (personalization and decollectivization of behaviour);

- they will take self-guided tours, at their own pace and the museum will provide access to information according to their own interests and when they wish to receive it;

- moreover, on the one hand, they are sensitive to the context of the museum exhibits presented (e.g. in what political and social contexts they were created, what their reference is to the present day etc.), whereas, on the other, to an attractive and often interactive formulas of presentation (light, sound, motion, image);

- they more frequently desire to visit a museum without the need for their physical presence in its space, but owing to virtual access to exhibits 
(unofficial consumption of culture, privatization and home-centred participation in culture);

- they are more inclined to visit those museums which change and develop their offer, enriching it with new exhibits, temporary exhibitions, educational and didactic proposals and also cultural events.

To meet these requirements, museums - apart from presenting exhibits - surprise their visitors with cinema rooms, music and background sounds, interactive showcases, plays of lights, scents or devices, and rooms where certain impressions can actually be experienced (e.g. seismic tremors in the Tech Museum of Innovation in San Jose, California). The experiences resulting in certain emotions remain the basic component of a contemporary museum product (thrill, compassion, sense of responsibility etc.). Purely visual reception, moving from exhibit to exhibit and possibly listening to anecdotes told by a museum guide are no longer sufficient. Experiencing, touching, having a 'first-hand' feeling - stand exactly for what modern customers expect. These preferences are best reflected by metaphors used to describe museum visitors: explorer, analyst, listener, creator, player and an individual seeking social contacts (TOMIUC 2014, pp. 33-46). Therefore, the thesis about the multi-sensory nature of museums, focused on triggering emotions and developing relationships and values for clients by creating a friendly, engaging space - the place of desired returns - by preparing products which appeal to the multi-sensory essence of a human, is confirmed. Cultural events, serving as a tool for creating individual, deep and unforgettable experiences remain a frequent component of this offer.

Higher attendance can be probably expected in these museums which (WALTL 2006, pp. 1-7, IDZIAK 2007, HEIJNEN 2010, pp. 13-23, KRUCZEK, KUREK \& NOWACKI 2012, p. 191, MCCALL \& GREY 2014, pp. 19-35, KRZYWORZEKA 2014, pp. 177-198, TOMIUC 2014, pp. 33-46, KAP 2016, pp. 100-132, GREFFE, KREBS \& PFLIEGER 2017, pp. 319-334, HÖLLING 2017, pp. 97-111):

- present their material using a narrative convention combining artefacts (original material exhibits) with iconography, photography, reconstruction, scenography and audio-visual materials (audio recordings, films);

- use narration appropriate to a museum theme (e.g. patriotic, ideological, scientific), developed based on proven principles, conveyed in a dynamic and interactive manner using modern forms of expression and storytelling (multimedia, extended space);

- present their resources and ideas based on context, which adapt the museum product better to the needs of different customer profiles;

- use simulated practices and replicas of exhibits to revive the exhibition and deepen the sense of immersion in the presented environment, which allows for the creative and emotional involvement of visitors in the history and events presented by the museum;

- represent an institution which provides visitors with a great deal of satisfaction and comprehensively meets their diverse needs from the past and present, getting to know the history, ideas, heroes, through acquiring knowledge, learning, conducting research, social gatherings, spending time with the family, participation in culture and entertainment, thus allowing relaxation;

- are prepared to serve different market segments by offering preferences tailored to their age;

- recognize that an important part of their audience is represented by museum visitors using a virtual tour, in many cases the number of people interested in making an online visit is significantly larger than the number of visitors in reality. For this part of the audience museums are developing attractive web-based solutions for taking advantage of museum resources (virtual tours of exhibitions, virtual descriptions of exhibits, videotransmissions of events),

- acknowledge the growing number of visitors 'armed' with smartphones and other mobile devices, which can be used to increase the audience's involvement in the museum, enrich their experiences, develop participatory sightseeing and construct space for dialogue with museum visitors.

Modern museums are not just collections of valuable artefacts exhibited and protected for future generations but represent the products of culture as if goods offered for sale and, thus, should be adapted to the needs and expectations of the market, including in particular, the reduction of distance (e.g. spatial, intellectual, informative) between the exhibits and their visitors ${ }^{5}$. Attracting visitors requires providing an extensive offer, with a variety of proposals complementary to their primary activity - a permanent exhibition. Temporary exhibitions, 'openings' and 'closings', museum lessons, workshops (in painting, photography, music), academic symposiums, expert lectures, meetings with interesting people, concerts, smaller and larger theatrical forms, social meetings, festival celebrations, banquets and official dinners are increasingly frequently included in the calendar of museum events, becoming an integral component offered by every museum in Poland or worldwide. For this reason, museums providing space for recreation, social interaction, contemplation, or evoking emotions are currently quite common (WALTL 2006, pp. 1-7), and their social role, openness to wider audience, active tours, through their interdisciplinary nature and modern communication methods, as well as new relationships between museums and societies or 
the communities in which they function are decisive for modern museology (VERGO 1989, HEIJNEN 2010, MCCALL \& GRAY 2014).

\section{THE GERHART HAUPTMANN MUSEUM (GHM) AS A SPACE FOR CULTURAL RECREATION}

When looking through the offers and timetables presented on the websites of Polish museums an important conclusion can be drawn about the significant position of cultural events in a museum product. In 100 Polish museums, selected by systematic sampling 6 , based on the information provided on their websites, from several up to 25-30, smaller or larger cultural events are organized annually. The case study of GHM in Jelenia Góra-Jagniątków (Photo 1) was used to verify the thesis put forward in the introduction regarding the integral role of cultural events as a component of a museum's product structure. For this reason a detailed description of the museum's offer was presented (based on reports about the institution's activity in 2011-16), attendance levels were analysed including the share of special event participants (source materials), and attendance at such events was placed in the set of motivations of visitors (interviews with $25^{7}$ visitors conducted in the museum in the first half of 2016), as well as the reasons underlying the museum's offer extension by such events (interviews with the manager and members of the Museum Council during its session in 2016). Purposive sampling, covering several criteria, was selected for study purposes. The respondents were chosen from among tourists (the residents of Jelenia Gora and its surroundings were excluded from the study) who were at least 18 years of age and visited the GHM outside the dates of cultural events ('typical' visitors arriving in the museum to see its permanent exhibition). Discussion on the main issue was preceded by presenting the origin and idea behind GHM due to its unusual nature. It is one of the few literary museums in Poland and, surprisingly, was devoted to a great foreign author. Except for the architecture of the building itself and certain decorative elements, it cannot offer many valuable exhibits, and in this case, they are probably an insufficient factor to attract tourists. Apart from the substantive criteria in selecting the research subject, practical reasons were also important: the availability of information and low cost of research.

The GHM is situated in one of Jelenia Gora's districts (Jagniątków) and dedicated to the German writer Gerhart Hauptmann (Photo 2) - the Nobel Prize laureate. It is located in the writer's villa, in which he lived for almost half a century before his death. The building itself, dating from 1901, remains an interest- ing example of residential architecture, combining elements of historicism and the neo-Renaissance. It was listed among the historical monuments of Jelenia Góra region in 1985 and, with its decor and furnishings as well as the surrounding park, constitutes its primary purpose - the most important resource of the museum.

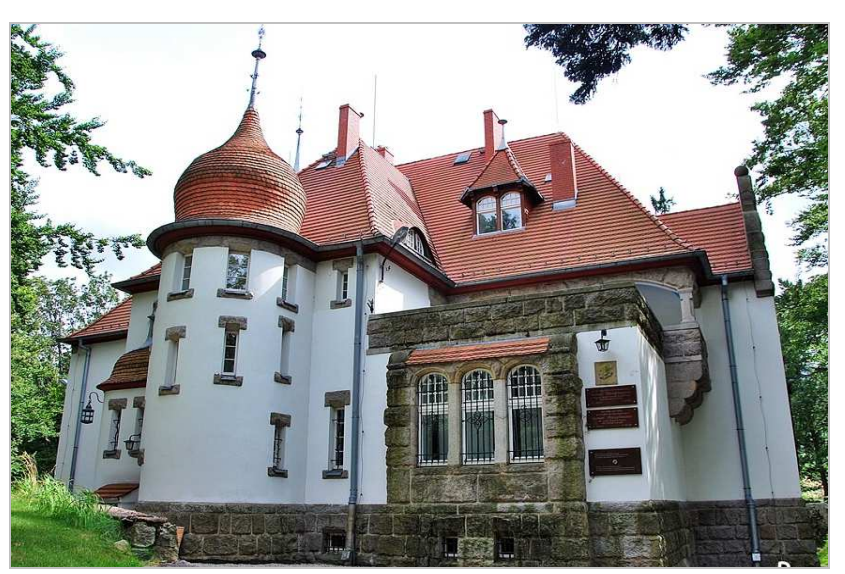

Photo 1. The Gerhart Hauptmann Museum in Jelenia Góra-Jagniątków

Source: http://www.muzeum-dgh.pl/

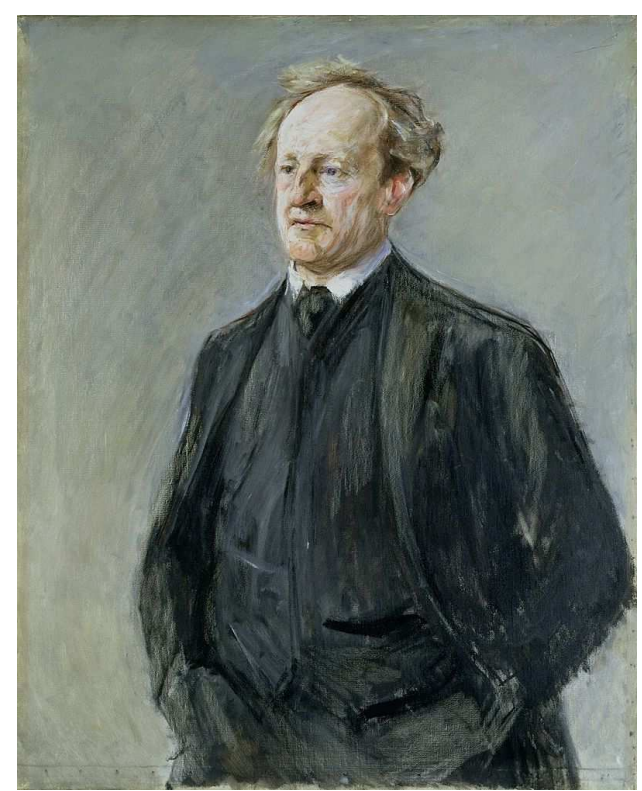

Photo 2. Portrait of Gerhart Hauptmann Source: http://www.muzeum-dgh.pl/

The museum presents the very interesting history of Hauptmann's life (especially his declining years). He was a poet, a playwright and a socialist writer, a Nobel Prize laureate, a rich man, a traveller, a rebel, a celebrity and above all a German citizen, who after World War II found himself in the area of the so-called 'Recovered Territories'. With the permission of secret police (NKVD) and the emerging new Polish authorities in Silesia, he 
was allowed to stay in his own home. After his death, which happened just one year after the surrender (6 ${ }^{\text {th }}$ June 1946), it was agreed to take the writer's body to Germany where he was buried. Most of the villa's furnishings were also taken away at that time. Thus the museum's items are relatively modest: an original manuscript closet with the relief of a girl; the sofa on which the writer's body was laid; the cast of his hand and the copies of his post-mortem mask, of his family album, his Nobel Prize certificate and the villa guestbook from the 1930s are among the most important. The most valuable is the 1922 polychrome by J.M. Avenarius covering the walls and the ceiling of the hall called, owing to the painting, the 'Paradise Hall'. It presents paradise with scenes showing Hauptmann's life and work.

The idea of the museum dates back to 1989 and was the consequence of a joint statement by the German Chancellor Helmut Kohl and the Prime Minister of the Republic of Poland Tadeusz Mazowiecki. For this reason a thorough renovation of the building, with the financial support of the German Federal Government and the Foundation for Polish-German Cooperation was undertaken. GHM as a cultural institution of the city of Jelenia Góra was opened in 2001 and was awarded museum status on $1^{\text {st }}$ May 2005. Jelenia Góra Council acts as the subsidizing organizer of the museum's current activity. In 2011-15 the average annual subsidy earmarked amounted to about PLN 465 000, including only PLN 20000 for organizing events. In 2012 - called the Year of Hauptman - the museum received an additional designated subsidy amounting to PLN 40200 to prepare and carry out the events celebrating two anniversaries: the artist's $150^{\text {th }}$ birthday and $100^{\text {th }}$ anniversary of his Nobel Prize. Including its own revenues and other grants, in the period analysed, the museum had at its disposal an average annual budget of approx. PLN 778 000. This amount is PLN 228000 (41.5\%) higher than the funds available for museums in smaller municipalities in Poland. The latter, according to studies carried out by the National Institute for Museums and Public Collections (MURZYN-KuPISZ 2016, p. 93), in 201315 , had at their disposal an average annual budget of PLN 550 000, which is significantly less than those in larger locations (PLN 3.4 million). In the period 201115 , the share of earmarked and designated subsidies in total revenues reached $67 \%$. Due to the fact that the museum presents the achievements of a great German writer, it is also funded by German institutions (e.g. the German Federal Government, the governments of Saxony, Brandenburg and Mecklenburg-Western Pomerania, the town of Ekner and the Cultural Foundation of the Free State of Saxony). These annual average funds amount to $13-15 \%$ of the earmarked subsidy.

The museum was planned to be a traditional museum of exhibits. Gradually the museum was supple- mented by elements characteristic for a narrative museum (electronic information, movie screenings, touring exhibitions, thematic temporary exhibitions (a multimedia interactive exhibition offering a visitor an option to choose the content he/she wants to read). Obviously, the museum's primary purpose is to preserve the historic monument (villa) and the museum exhibits, but also to inform the public about the value and significance of the accumulated collections, to popularize the history of Gerhart Hauptmann's life and work, to study and disseminate knowledge about the past and the culture of Lower Silesia.

The active functioning of the museum is connected with an abundant offer of both minor and major cultural events. In the period 2011-15 about 15-25 of such events were held each year. Many of them are regular and are recognised by visitors. Among them there are 'European Days', 'Open-Door Day', 'European Days of Heritage', 'The Night of Museums', 'The Musical Garden of Rübezahl', 'Giant Mountains Integration Literary Christmas Eve', and celebrations for Hauptmann's birthday. Every year between two and five new temporary thematic exhibitions about Hauptmann or regional issues are held (e.g. 'Hauptmann and the Giant Mountains', 'Hauptmann and the Silesian Nobel Prize Winners', 'Hauptmann and movies', 'Father and son', the cycle of exhibitions 'Hauptman and friends', 'The Black Mask', 'The Weavers', 'Thiel the Ditcher', 'The Giant Mountains on old postcards', 'Salons and literary manor houses on both sides of the Oder', open-air exhibitions e.g. Artistic inspirations of the Giant Mountains and the Hauptmann Trail). Some of these proposals later become touring exhibitions, finding hospitable space not only in other museums in Poland, but all over the world (USA). GHM invites exhibitions from other institutions, including touring exhibitions from Polish and German museums.

The exhibitions are accompanied not only by ceremonial 'openings' and 'closings'. Literary gatherings and discussions remain an important form of such events (e.g. Conversations by the fireplace, lectures in the series The Giant Mountains - a place of cultural dialogue) and concerts (e.g. The New Year Concert, The Stars promote..., The Musical Garden of Rübezahl). Musical accompaniment, provided by the Jelenia Gora Concert Hall philharmonic and students from Jelenia Góra music schools is often present during cyclical events. The proposals for cultural recreation inspire and attract diverse audiences and take the form of competitions (literary, artistic, music) and also spectacular open-air events and workshops (e.g. cross-border chamber music workshops, Young people on the Jelenia Góra palace trail, tree pruning in the park surrounding the museum based on the rule nothing is wasted, and Polish-German sculpture Workshops organized following the principle of social and environmental responsibility adopted by the museum). A typical offer also includes special 
events Women's Day, Children's Day or a Santa Claus party at Hauptmann's. These events confirm the social orientation of the museum, aimed at developing and maintaining relations with local communities. The offer is completed by conferences, symposia and seminars organized either independently or as a cooperating partner.

Interesting and attractive proposals for spending time in the museum are reflected in the attendance. Cultural events attract $c a$ 2500-3000 visitors per year (16$20 \%$ of average visitor numbers -15054 in 2011-15). This, however, is not included in the total visitor numbers, because the museum management take into account only individual visits or group tours.

It is not surprising that the majority of visitors are from Germany (annual average of approx. 70\%), predominantly senior citizens connected by their roots with the Silesian region. They are attracted by the relationship between the museum and their fatherland. Among the motivations reported by the visitors to GHM (based on personal interviews) - the most important one was the permanent exhibition, primarily the 'Paradise Hall' (two fifths of the respondents), followed by the museum location in a tourist region (one quarter) and museum exhibitions (one fifth). Every tenth respondent was interested in the person of Gerhard Hauptmann, which may result from the fact that the German Nobel Prize winner is not widely known among Poles (30\% of all $\mathrm{GHM}$ visitors). It is uncommon for tourists to participate in other cultural events, apart from the temporary exhibitions. Sometimes they happen to come across them accidentally when their visit to the region coincides with the event date. Thus, cultural events activate mainly the local community and people particularly interested in the person and achievements of the Nobel Prize winner (students, academics, artists). They constitute the major share among event participants (based on the interview with the museum manager).

What is the reason for organizing cultural events by the GHM and undertaking such a great organizational effort by the small group of people employed (seven members of staff)? Based on the interview with the manager it is obvious that this work is primarily their passion, to be followed by a well-approached duty (the museum exists for its visitors, so the offer has to be interesting), the desire to activate the local community and counteract the crisis of participation in culture (activities aimed at higher attendance), promotion and image-oriented aspects, as well as financial issues - the possibility of raising money for substantive activities by taking advantage of various museology and culture support funds. The underlying motive is not just to increase its own revenues from selling admission tickets to events. This spectrum of reasons listed by the manager is supplemented by an additional one expressed by the
Museum Board members - and also the basic condition for the success of events organized in the GHM - i.e. the deep involvement and creativity of the museum staff.

\section{CONCLUSIONS}

Recent years have been characterized by a systematic increase in the number of museums in Poland. Unfortunately, only $20 \%$ out of 926 museums functioning in 2017 have reported an increase in the number of visitors. In the other museums the figure is relatively low. Therefore, museums undertake such activities as organizing interesting cultural happenings, which represent deliberately designed, time and space-specific events aimed at creating and disseminating culture. One of these museums is the Gerhart Hauptmann Museum in Jelenia Góra-Jagniątków. Analysis of the case study showed that cultural events have currently become an integral part of the museum's product. Owing to these, visitors to the museum have increased by about $20 \%$ annually, and its own revenues have increased too, mainly from subsidies from sponsors who provide support specifically for cultural events. Interestingly, the events act as an attracting force for the local community to visit the museum as well as activate its participation in culture. In this case, not only do they play an important marketing role as a product component or a promotional tool in constructing the museum image, but also reach out to the expectations of modern visitors and set a pro-social direction for museum activities.

\section{ENDNOTES}

1 According to many linguists it would be more correct to use the term "culture-oriented". Nevertheless, due to the popularisation of the term "cultural events" in Polish language, the authors have maintained its traditional name. Moreover, the Dictionary of Polish Language published by the Polish Academy of Sciences (PWN) allows using both terms, i.e. cultural and a culture-oriented to convey the relationship of something with culture.

2 According to the list of museums comprising institutions operating on the basis of the statute or regulations agreed with the Ministry of Culture and National Heritage (as of 20th October 2017), http://bip.mkidn.gov.pl/pages/rejestry-ewidencje-archiwawykazy/rejestry-muzeow.php.

${ }^{3}$ More on this problem in the reports on the state of museology in Poland cited in the article, i.e. D. FOLGA-JANUSZEWSKA (2008) and Museums in Poland... (2016).

4 Based on own observations and experiences as a long-standing member of museum councils and opinions expressed by museology experts presented on http://www.museum-id.com/idea-detail. asp?id=283.

${ }^{5}$ E.g. Guggenheim Museum in New York can be perceived as a culture oriented enterprise, which extends its business through the sale of franchise. Currently it runs its divisions in Bilbao, Venice, Berlin and Las Vegas. 
6 The sampling was organized by the Minister of Culture and National Heritage (as at 20 $0^{\text {th }}$ October 2017), http://bip. mkidn. gov.pl/pages/rejestry-ewidencje-archiwa-wykazy/rejestry -muzeow.php.

7 In the case of an in-depth interview as a qualitative method of data collection, the number of respondents does not have to be large. In the theory of qualitative research no specific rules for determining the sample size have been finally specified. It is only recommended to determine it on the basis of research objectives, the nature of research, available resources and time at the researcher's disposal (PATTON 1990, MORSE, 2000). The actual sample size generally ranges from a few to several dozen people (MORSE 1994, CRESWELL 1998).

\section{BIBLIOGRAPHY}

ALLEN J., 2009, Event planning: The ultimate guide to successful meetings, corporate events, fundraising galas, conferences, conventions, incentives and other special events, John Wiley \& Sons Ontario, Canada, pp. 448, 978-0-470-15574-5.

BLADEN C., KENNELL J., ABSON E., WILDE N., 2012, Events management, Routledge, Oxon, pp. 440, ISBN: 978-0-415-57742-7.

CRESWELL J. W., 1998, Qualitative inquiry and research design: Choosing among five traditions, Sage Publications Inc., Thousand Oaks, CA, pp. 403, ISBN: 978-0-761-90144-0.

FOlgA-JANUSZEWSKA D., 2008, Muzea w Polsce 1989-2008. Stan, zachodzące zmiany i kierunki rozwoju muzeów w Europie oraz rekomendacje dla muzeów polskich, raport dla Ministerstwa Kultury i Dziedzictwa Narodowego, Warszawa.

GETZ D., 2005, Event management and event tourism, Cognizant Communication Corporation, New York, pp. 439, ISBN: 978-1-882-34546-5.

GETZ D., 2008, Event tourism: Definition, evolution, and research, Tourism Management, 29, pp. 403-428.

GETZ D., PAGE J.S., 2016, Progress and prospects for event tourism research, Tourism Management, 52, pp. 593-631.

GOLDBLATT J., 2002, Global event special events: Twenty first century management, John Wiley \& Sons Inc., New York, pp. 459; ISBN 0-471-39687-7.

GREFFE X., KREBS A., PFLIEGER S., 2017, The future of the museum in the twenty-first century: recent clues from France, Museum Management and Curatorship, 32 (40), pp. 319-334.

HEIJNEN W., 2010, The new professional: Underdog or Expert? New Museology in the 21 $1^{\text {th }}$ century, Sociomuseology, 3 (37), pp. 13-23.

HöLLING H.B., 2017, Lost to museums? Changing media, their worlds, and performance, Museum History Journal, 10 (1), pp. 97-111.

IDZIAK W., 2007, Wspótczesne tendencje w muzealnictwie, http://muzeoblog.org/files/W_Idziak_Wspolczesne_tende ncje.pdf, 25.02.2018 r.

JAGO L.K., SHAW R.N., 1998, Special events: A conceptual and definitional framework, Festival Management \& Event Tourism, 5, pp. 21-32.

KAP M., 2016, Muzeum w dobie konwergencji i nowych mediów - nowe trendy, nowe technologie, nowe możliwości, Kultura - Media - Teologia, 25, pp. 100-132.

KRUCZEK Z., 2017, Frekwencja w polskich atrakcjach turystycznych 2011-2015. Dynamika, trendy, studia przypadku, Proksenia, Kraków, pp. 200, ISBN: 978-83-60789-66-7.
KRUCZEK Z., KUREK A., NOWACKI M., 2012, Krajoznawstwo. Teoria i metodyka, Proksenia, Kraków, pp. 240, ISBN: 978-83-60789-01-8.

KRZYWORZEKA P., 2014, Muzea w pogoni za nowoczesnością. O możliwościach wykorzystania etnografii w zarządzaniu i zarządzania w etnografii, Zbiór Wiadomości do Antropologii Muzealnej, 1, pp. 177-198.

Kultura w 2007 r., 2008, GUS, Warszawa.

Kultura w 2009 r., 2010, GUS, Warszawa.

Kultura w 2015 r., 2016, GUS, Warszawa.

LORD B., LORD G.D., 1997, The manual of Museum Management, Altamira Press, Walnut Creek-London-New York-Oxford.

MATTHEWS D., 2008, Special event production: The process, Butterworth-Heinemann, Oxford, pp. 266, ISBN: 978-0-7506-8243-5.

MATTHEWS D., 2016, Special event production: The process, Rutledge, London-New York, pp. 264, ISBN: 978-1-138-78565-6.

MCCALL V., GREY C., 2014, Museums and the 'new museology': theory, practice and organizational change, Journal of Museum Management \& Curatorship, 29 (1), pp. 19-35

MORSE J.M., 2000, Determining sample size, Qualitative Health Research, 10 (1), pp. 3-5.

MORSE J.M., 1994, Designing funded qualitative research, [in:] N.K. Denzin, Y.S. Lincoln (eds.), Handbook of qualitative inquiry, Publication Sage, Thousand Oaks, CA, pp. 220-235, ISBN: 978-0-803-94679-8.

MURZYN-KUPISZ M., 2016, Spoteczno-ekonomiczne aspekty funkcjonowania muzeów: zatrudnienie, przychody $i$ wydatki instytucji muzealnych, [in:] Muzea w Polsce. Projekt statystyka muzeów (2013-2015), NIMOZ, Warszawa, pp. 81-117.

Museums Association, 2015, Cuts survey 2015. Report, www.mu seumsassociation.org; $24.10 .2017 \mathrm{r}$.

Museums Association, 2017, Museums in the UK 2017. Report, www.museums association.org; $24.10 .2017 \mathrm{r}$.

Museums in Poland. Reports based on data from the project Museum statistics (2013-2015), 2016, National Institute of Museology and Collection Protection, Warsaw.

PATTON M.Q., 1990, Qualitative Evaluation and Research Methods, Sage, Newbury Park, California.

Special Eurobarometer 399. Cultural Access And Participation Report, 2013, European Commission.

STASIAK A., 2010, O potrzebie rewolucji w polskim muzealnictwie XXI wieku, [in:] Kultura i turystyka - razem czy oddzielnie?, A. Stasiak (ed.), Wyd. WSTH, Łódź, pp. 117-134.

VERGO P., 1989, The new museology (Chapter one), [in:] The new museology, P. Vergo (ed.), Books, London, pp. 10-23.

Themed Entertainment Association (TEA), 2016, The global attractions attendance report, 2016. Theme index and museum index, www.TEAconnect.org, 24.02.2018 r.

TOMIUC A., 2014, Navigating culture. Enhancing visitor museum experience through mobile technologies. From smartphone to google glass, Journal of Media Research, 7, 3 (20), pp. 33-46, ISSN: $1844-8887$.

WALTL CH., 2006, Museums for visitors: Audience development - A crucial role for successful museum management strategies, INTERCOM 2006, Conference Paper, Taiwan: ICOM, pp. 1-7, http://www.intercom.museum/Taiwan 2006a.html, 18.10.2017 r.

https://sjp.pwn.pl/sjp-local/slowniki.

Article rceived:

7 November 2017 Accepted:

12 February 2018 